DOI 10.18551/rjoas.2019-11.23

\title{
ANALYSIS OF WATER QUALITY AND DISTRIBUTION OF HARA IN SEMAU STRAIT KUPANG EAST NUSA TENGGARA
}

\author{
Suseno*, Nyoman Sudiarsa I., Lecturers \\ Kupang Polytechnic Marine and Fisheries, East NusaTenggara, Indonesia \\ Gofar Ismail Ece, Djoko Surahmat, Lecturers \\ Sidoarjo Polytechnic Marine and Fisheries, East Java, Indonesia \\ *E-mail: caknash64@gmail.com
}

\begin{abstract}
Waters of the Sawu Sea is very dynamic because it is a meeting of the two masses of water from the Indian Ocean and the Banda Sea. The upwelling phenomenon or mass agitation in cold seawater and warm surface water makes this region an area with very high water productivity. The research purpose is to inform the condition of the water quality and nutrient distribution of Semau strait whether it can be used for the cultivation of fish. The paper presents the result of study which is showed. The average temperature at the sea surface is $26.25^{\circ} \mathrm{C}-28.79^{\circ} \mathrm{C}$; the turbidity value range from 0.66 to $4.21 \mathrm{NTU}$; The brightness from 15.6 $\mathrm{m}$ to $20.3 \mathrm{~m}$ highest brightness occurred on Station 2 is 20.3: The speed of surface currents is ranged from 0.05 to $0.065 \mathrm{~m} / \mathrm{sec}$; levels of phosphate $\left(\mathrm{PO}_{4}\right)$ ranged from 0.095 to 0.352 $\mathrm{mg} / \mathrm{I}$ (average $0,137 \mathrm{mg} / \mathrm{I}$ ); levels of nitrate $\left(\mathrm{NO}_{3}\right)$ from 0.24 to $1.31 \mathrm{mg} / \mathrm{L}$ (mean $0.42 \mathrm{mg} /$ $\mathrm{L})$. The lowest nitrate levels are found in Station 4 is $0.24 \mathrm{mg} / \mathrm{L}$; Nitrite content in the waters of Semau strait ranges between 0,006- $0.108 \mathrm{mg} / \mathrm{I}$ and Ammonium of $0.424 \mathrm{mg} / \mathrm{I}$.
\end{abstract}

\section{KEY WORDS}

Semau strait, water quality, region, seawater.

Semau Strait is sea between Timor and Island Semau, or rather is in the District of West Kupang, East Nusa Tenggara. Semau Strait is actually including the Savu Sea, only hindered by Semau Island. Semau strait is arbitrarily also influenced by the movement of water between the Indian Ocean and the Banda Sea so that the characteristics of the waters and its oceanography are similar to the characteristics of the Savu Sea. But it is different because of its location in the form of the strait. Because Semau strait is including dynamic waters and many factors that influence success in aquaculture business, it is necessary to research these waters.

The research was conducted in August - December 2017 in Kupang coastal waters (Semau strait) which is waters between the island of Timor and Semauisland, or rather in the region of West Kupang East Nusa Tenggara. Equipment and materials used in this study are: Thermometer, refractometer, Phosfat kit, Nitrate kits, spectrophotometers, DO kit, pH paper, and Current drogue. Data collection methods used in this research is surveyed by direct observation in the field of water quality and oceanographic conditions. The monitoring of water quality is done vertically and horizontally spread at 10 observation stations so that it can be seen the distribution of water quality in coastal waters of Kupang either vertically or horizontally. The data collected in this study is the temperature, salinity, transparency, turbidity, current velocity, ammonia, ammonium, nitrite, nitrate, and phosphate,

The data were analyzed by water quality using the Water Quality Index (Shweta Tyagi, Bhavtosh Sharma, Prashant Singh, Rajendra Dobhal, 2013) , or IKA is often called the WQI (Water Quality Index) with the aid of a test device Water Quality Index Calculator. The data were also analyzed descriptively by comparing observations of water quality with environmental quality standards for aquaculture. 


\section{RESULTS AND DISCUSSION}

The average temperature at the sea surface in Semau strait research sites during the observation ranged between $26,25^{\circ} \mathrm{C}-28,79^{\circ} \mathrm{C}$, llahude and Gordon (1996), for the Southeast Monsoon, the Flores sea surface temperature, the Sawu sea decreases to be below $28^{\circ} \mathrm{C}$ and decreases again to the Banda Sea in the range of $26.1^{\circ} \mathrm{C}-27.40^{\circ} \mathrm{C}$.In general, the water temperature at all stations in Semau strait is in good condition and suitable for marine aquaculture

The results of the analysis of turbidity at Station 1 to Station 10 show the turbidity value range from 0.66 to $4.21 \mathrm{NTU}$. In general, the turbidity value in Semau strait is relatively low and does not exceed the seawater quality standards for marine life activity (LH Decree No. 51 of 2004).

The brightness of the observations in Semau strait ranged from 15.6 to $20.3 \mathrm{~m}$. The highest brightness occurred on Station 2 is $20.3 \mathrm{~m}$ for the beaches of the bottom water are sand and rubble. Judging from the brightness of the waters, all the observation stations are a suitable location to be the location of mariculture.

The speed of surface currents in Semau strait at Station 1 to Station 10 ranged from 0.05 to $0.065 \mathrm{~m} / \mathrm{sec}$. However, the current speed at Stations 1 and 10 is higher than the other stations, this is because the location of the station is directly adjacent to the Indian Ocean and is located on a narrow section of the waters in Semau strait. Current speed when passing the narrower gap will experience greater speed. Overall, the current speed of all the stations is very supportive for marine aquaculture activities.

Overall, levels of phosphate (PO 4) in the Strait of Semau ranged from 0.095 to 0.352 $\mathrm{mg} / \mathrm{I}$ (average 0,137 $\mathrm{mg} / \mathrm{I}$. Phosphate levels in these waters are lower than in the waters of the island of Simeulue, Aceh (Anonymous, 2007) (0.04 to $3.51 \mathrm{mg} / \mathrm{L}$ ), Judging from phosphate levels as an indicator of fertility, Semau strait is still good for aquaculture. The good phosphate levels for the cultivation of Green Shellfish and Shellfish range 0.5-1.0 $\mu \mathrm{gA}$ / $\mathrm{L}(\mathrm{KMNLH}, 2004)$ for the cultivation of oysters ranged from 0.5 to $3.0 \mu \mathrm{gA} / \mathrm{L}$ while for the cultivation of rabbit fish, snapper, and grouper range from 0.2-0.5 $\mu \mathrm{gA} / \mathrm{L}(\mathrm{KMNLH}, 2004)$.

Overall, levels of nitrate $\left(\mathrm{NO}_{3}\right)$ in the waters of Semau strait ranges from 0.24 to 1.31 $\mathrm{mg} / \mathrm{L}$ (mean $0.42 \mathrm{mg} / \mathrm{L}$ ). The lowest nitrate levels are found in Station 4 is $0.24 \mathrm{mg} / \mathrm{L}$ and the highest is in station 9 with a level of $1.1 \mathrm{mg} / \mathrm{L}$. High level of nitrate in station 9 is because the station is adjacent to the mangrove ecosystem but these waters are still good for the business of aquaculture.

The presence of nitrite in the water illustrates the ongoing process of reforms of biological organic material that has low dissolved oxygen (Effendi, 2003). The observation of nitrite content in the waters of Semau strait ranges between $0,006-0.108 \mathrm{mg} / \mathrm{I}$ and the nitrite content is not harmful for Aquaculture.

The results showed that the average value of the content of ammonium in Semau strait of $0.424 \mathrm{mg} / \mathrm{I}$ indicates a higher value than the average value of the content of ammonium in the coastal waters of the Flores Sea $(0,201 \mathrm{mg} / \mathrm{I})$. The high value of the content of ammonium is due to the high activity of the decomposition of organic matter by bacteria and other micro-organisms. So that cultivation can be developed in areas far from the mouth of the river.

The good degree of acidity for fish life ranges from 5-9 and 6.5 to 8.5 (KMNLH, 2004). The $\mathrm{pH}$ value in Semau strait ranged from 7.85 to 8.21 with an average of 8.08 , which is still considered adequate for aquaculture. Overall, the levels of dissolved oxygen (O2) in the waters of Semau strait ranged from 5.32 to $7.10 \mathrm{ppm}$ (average $6.21 \mathrm{ppm}$ ). The minimum requirements for aquaculture are $4 \mathrm{ppm}$ so that this condition still allows for aquaculture. Salinity in the sea surface layer of Semau strait during the observation varied between 33,62 $33,97 \mathrm{PSU}$ with an average of $33.86 \pm 0.10 \mathrm{PSU}$. The distribution pattern of salinity, in general, in these waters, is not very significant. 


\section{CONCLUSION}

The value of WQI is 79. It is generally still considered "good" and suitable for the development of marine aquaculture. The distribution of nutrients in the waters of Semau strait did not spread evenly with a nitrate content ranged from 0.24 to $1.31 \mathrm{mg} / \mathrm{L}$ with an average of $0.42 \mathrm{mg} / \mathrm{L}$ and phosphate content ranges 0.095 to $0.352 \mathrm{mg} / \mathrm{I}$ with an average of $0,137 \mathrm{mg} \mathrm{/} \mathrm{I}$. The waters of Semau strait are very fertile and suitable for marine aquaculture activities. Suggested the need for further research on water quality conditions and the distribution of nutrients in the waters of Semau strait for this waters is very dynamic because it deals directly with the waters of the Indian Ocean and the Banda Sea and the study was not conducted during the year.

\section{ACKNOWLEDGEMENTS}

This work was partially supported by Polytechnic of Marine and Fisheries of Kupang. This research was done financially supported by research fund of Polytechnic of Marine and Fisheries of Kupang. The authors are very grateful to field staff and laboratory staff who have supported our research data. Sincere thanks to anonymous privacy for their help. Critical comments and suggestions are important for improving the manuscript.

\section{REFERENCES}

1. APHA (American Public Health Association). (2005). Standard Methods for the Examination of Water and Wastewater, 21st Edition. American Water Works Association (AWWA) / American Public Works Association / Water Environment Federation. Washington, USA, $1368 \mathrm{pp}$.

2. Effendi, H. 2003. Assessing Water Quality for Management of Water Resources and Environment. Fifth mold. Yogyakarta: Canisius.

3. KMNLH. 2004.Pedoman determination standard Environmental Quality. Office of the Minister for Population and the Environment 2004. State Minister for Population and Environment. Kep-51 / MENEGLH / 2004, the State Secretariat, Jakarta.

4. Kannel, PR, Lee, S., Lee, Y.-S., Kanel, SR, \& Khan, SP (2007). Application of Water Quality Indices and dissolved oxygen as indicators for river water classification and urban impact assessment. Environ. Monit. Assess., 132, 93-110.

5. Kocer, MAT, and Sevgili, H. (2014). Parameters selection for water quality index in the assessment of the environmental impacts of land-based trout farms. Ecological indicators. 36: 672-681.

6. Lobato, TC, Hauser-Davis, RA, Oliveira, TF, Silveira, AM, Silva, HAN, Tavares, MRM, and Saraiva ACF (2015). Construction of a novel water quality index and quality indicators for reservoir water quality evaluation: A case study in the Amazon region. Journal of Hydrology. 522: 674-683

7. Lumb, A., Sharma, TC, and Jean-François Bibeault. (2011). A Review of Genesis and Evolution of Water Quality Index (WQI) and Some Future Directions. Water Qual Health Expo. 3: 11-24

8. Nybakken, JW 1997. Sea Biology: An ecological approach. Third printing. PT Gramedia. Jakarta. 480 pages.

9. Pesce, SF, \& Wunderlin, DA (2000). Use of water quality indices to verify the impact of Córdoba City (Argentina) on Suquía River. Water Research. 34 (11): 2915-2926

10. Radiarta, IN, and Erlania. (2015). Index of water quality and nutrient distribution around an integrated marine aquaculture in Gulf waters Ekas, West Nusa Tenggara: an important aspect of seaweed farming. Aquaculture Research Journal 10: 141-152.

11. Santoso, AD 2007. Substance Nutrient Content Phosphate in West season in the Gulf and East season Hurun, Lampung. Journal of Environmental Engineering., 8 (3): 207-210 
12. Shweta Tyagi, Bhavtosh Sharma, Prashant Singh, 2013. Water Quality Assessment in Terms of Water Quality Index, Available online at http://pubs.sciepub.com/ajwr/1/3/3, American Journal of Water Resources, 2013, Vol. 1, No. 3, 34-38

13. Simanjuntak, M. 2007 Dissolved Oxygen and Apparent Oxygen Utilization in Klabat Gulf waters, Bangka Island. Journal of Fisheries (Journal of Fisheries Sciences., XII (2): 5966.

14. Simanjuntak, M. 2007. Dissolved Oxygen and Apparent Oxygen Utilization in Banten Gulf waters. Marine Science, 12 (2): 61-65

15. Simões, FdS, Moreira, AB, Bisinoti, MC, Gimenez, SMN, and Yabe MJS (2008). Water quality index as a simple indicator of aquaculture effects on aquatic bodies. Ecological indicators. 8: 476-484.

16. Tomascik, T., AJ Mah, A. Nontji \& MK, Moosa. 1997. The Ecology of Indonesian Seas. The Ecology of the Indonesian Series. Vol. VII. Periplus Eds. (HK) Ltd., p1074

17. Wang, Y., Liu, D., Dong, Z., Di, Bm., \& Shen, X. (2012). Temporal and spatial distributions of nutrients under the influence of human activities in Sishili Bay, northern Yellow Sea of China. Marine pollution bulletin. 64: 2708-2719.

18. Whittaker, G., Barnhart, B., Fare, R. (2014). Application of index number theory to the construction of a water quality index: Aggregated nutrient loadings related to the areal extent of hypoxia in the northern Gulf of Mexico. Ecological Indicators. 49: 162168.

19. Wyrtki, K., 1961. Physical Oceanography of the Southeast Asian Waters. NAGA Rep. 2. Scripps Inst. of Oceanography, La Jolla, Calif., 195 p. 